\title{
Quantitative Analysis of Anthropomorphic Animals in Picture Books: Roles and Features of Animals
}

\author{
Kanae Hara*, Naoko Koda \\ Graduate School of Agriculture, Tokyo University of Agriculture and Technology, Tokyo, Japan \\ Email address: \\ s209229q@st.go.tuat.ac.jp (K. Hara),koda@cc.tuat.ac.jp (N. Koda) \\ ${ }^{*}$ Corresponding author
}

\section{To cite this article:}

Kanae Hara, Naoko Koda. Quantitative Analysis of Anthropomorphic Animals in Picture Books: Roles and Features of Animals. International Journal of Literature and Arts. Vol. 8, No. 6, 2020, pp. 308-315. doi: 10.11648/j.ijla.20200806.11

Received: October 24, 2020; Accepted: November 9, 2020; Published: November 19, 2020

\begin{abstract}
Children can have indirect contact with animals daily through media, such as picture books. Picture books can enrich children's imaginary world and help them develop an adaptive life that can cope with various experiences. Because anthropomorphic animals in picture books are a typical fantasy, they may contribute to the development of relationships between children and animals. Previous studies have mainly focused on children and anthropomorphic animals in picture books using qualitative or case-study methods. This study quantitatively examined the appearance of anthropomorphic animals in picture books by categorizing them by species (animal kinds). In 1,386 picture books, 178 species of anthropomorphic animals appeared. The most frequently depicted animals were, in order, rabbits, mice, and bears. The protagonists were often anthropomorphic animals, children and males. Different species of anthropomorphic animals had different characteristics in their sex and roles. Many picture books depicted bears, dogs, and foxes as males and rabbits and pigs as females. Bears were more likely to be protagonists, squirrels and foxes were less likely to be protagonists, and cats were less likely to act as supporting characters. These results reveal that children see various kinds of anthropomorphic animals in picture books, and that anthropomorphic animals in picture books reflect social images of animals and the history of human-animal interactions.
\end{abstract}

Keywords: Anthropomorphic Animals, Child Development, Depiction of Animals, Human-animal Interactions, Picture Books

\section{Introduction}

\subsection{Children and Picture Books}

Picture books have long been popular with children and have begun to attract broad social interest. Although sales of most paper publications have declined in a recent publishing slump, sales of children's books, including picture books, have been growing [1], and such books are the focus of efforts in early childhood education. In Japan, the section on language in National Curriculum Standard for Kindergartens of the Ministry of Education, Culture, Sports, Science and Technology [2] states that children should have a grasp of the language necessary for everyday life, to be familiar with picture books and stories, to enrich the sense for language, and to communicate feelings to teachers and friends.

Picture books are popular among young children in the home and in educational facilities. Children derive various forms of information from picture books by looking at them and by listening to adults read them aloud. Picture books can promote children's word learning [3-6] and enhance their knowledge and understanding of the world around them [7]. Abad and Pruden [8] reported that storybooks can change children's gender stereotypes, and Heath, Houston-Price and Kennedy [9] found that picture books about vegetables can encourage children to try to eat unfamiliar vegetables. Flevares and Schiff [10] demonstrated that picture books can promote children's learning of mathematics; for example, geometrical concepts. Ganea, Ma and DeLoache [11] found that picture books can provide children with biological information about real animals. Thus picture books are able to provide information about objects and concepts that which unfamiliar to children and may motivate them to take action. 


\subsection{Children and Animals in Picture Books}

Animals are attractive to children. Infants respond more interestingly to animals than to inanimate stimuli [12]. Children also respond more to animals than to in-animate toys [13]. Although children can have direct contact with animals through experiences such as caring for pets and visiting zoos, they can have indirect contact with animals daily through media, such as picture books. Although many picture books depict animals, the representations are often unrealistic [14], with animals depicted anthropomorphically, as if they are humans.

Children who are exposed to various images of animals and their habitats in everyday life through picture books may be misled because they receive incorrect information or form undesirable impressions [14]. Because anthropomorphic animals are fantastic beings, they are depicted as unrealistic features of picture books. Gaps between fantasy and reality may prevent children from transferring information from picture books to the real world [6]. Children who read picture books with realistic animals tended to develop biological reasoning patterns, while children who read anthropomorphic books adopted anthropocentric reasoning patterns [15]. Picture books of anthropomorphic animals may encourage children to ascribe human-like characteristics to animals, thus hindering their learning about biological facts and concepts [16].

However, anthropomorphism is not necessarily bad for children. Factual books are good for teaching children facts about animals, while books with fantasy are also important in fostering imagination and promoting cognitive development [17].

\subsection{Children's Imagination and Anthropomorphic Animal in Picture Books}

Imagination has the function of connecting and organizing various symbols. Children's imaginary worlds are formed by a combination of sensory and perceptual experiences and impressions from the realistic outside world [18]. At the end of infancy, children become able not only to recreate and imagine the things in front of them, but also to represent their experiences in their heads. In addition, 1-year-olds develop symbolic functions that associate referents with symbols; for example, by delayed imitation [19]. Representations are formed by indirect experience, such as reading novels, hearing stories from others, and experiencing emotions learned from other's lives, as well as one's own actual experience [20]. Rich experiences can lead to rich imagination, and picture books provide children the opportunity to enrich their experiences [21]. Thus picture books can enrich children's imaginary world and help them develop an adaptive life that can cope with various experiences. Because anthropomorphic animals in picture books are a typical fantasy, they may contribute to the development of relationships between children and animals.

\section{Purpose of This Study}

Previous studies have mainly focused on children and anthropomorphic animals in picture books using qualitative or case-study methods [6, 22]. This study quantitatively elucidated the features of anthropomorphic animals by focusing on their species and roles in picture books that children may encounter.

\section{Methods}

Following McCrindle and Odendaal [23], this study defined anthropomorphic animals in picture books as animals standing upright and walking only with their hindlimbs or hindlegs. Walking upright on two legs is an important biological feature of human evolution, and it is easy for children who read picture books to visually detect that such animals are anthropomorphic. However, based on the definition, the anthropomorphism of some animals, such as birds, mice, rabbits and bears, is difficult to judge because they are able to raise their upper bodies and support themselves using their lower bodies only. Thus additional criteria for judging animals with obvious human characteristics were defined, and animals that could be described in one of the following three ways were judged as anthropomorphic animals: (a) the tips of the forelegs were used to hold or grab something like a human and to make motions unrealistic for their species. (b) the forelegs were drawn in unrealistic orientations or balanced like a human, and (c) the balance of the hindlegs and the position of the body's center of gravity when the upper body was raised were depicted unrealistically, like a human's.

Data collection was conducted in 2019 on picture books stored on the open shelves of a city library in the suburbs of Tokyo, Japan as of 2018, the municipal library had 981,493 books and 381,620 users and was rooted in the lives of the residents through regular events such as reading picture books to children, book talks, and various hands-on activities. Narrative picture books for 2 to 7 -year-olds that contained anthropomorphic animals were surveyed. Excluded were picture books for infants, non-narrative picture books about words and poetry, picture books whose main purpose was intellectual education (such as science concepts), pop-up books, and picture books with collections of short stories. When there were four or more picture books in a series, we randomly selected three to use as samples, in order to reduce bias. The following information was recorded for each picture book.

1) Characters in the story: The features of the characters in the story were recorded. These included the presence or absence of humans in the story and the characteristics of the protagonist. When this was an anthropomorphic animal, its species, age group (child, adult, or senior), and sex were recorded. When the protagonist was a human, the person's age group (child, adult, or senior), and sex were recorded. When another object was the protagonist, its name was recorded. If the protagonist's age changed, for example, by growing up in the story, the age group in the main scene of the story was recorded. When it was difficult to distinguish the age group according to the pictures or sentences, age was recoded as unclear. Similarly, sex was classified as male, female, or 
unclear according to the picture, description and first-person pronoun.

2) Anthropomorphic animals: For an anthropomorphic animal, its species, sex, and role in the story were recorded. In many cases, it was difficult to accurately identify the species of animals based on biotaxonomics, due to the style of painting for children. Therefore, commonly used names were recorded for the anthropomorphic animals. For example, primates, were recorded as "monkeys," except for gorillas, which were easily distinguishable from the pictures. The roles of the characters in the picture books were defined as follows: protagonists were characters who played a main role in the story; supporting characters were designated in the text or were engaged in dialogue; and background characters were not described in the text and had no dialogue in the text but only appeared in the pictures. When it was difficult to determine the classification, two judges consulted.

\section{Result}

Of the 5,199 picture books examined, 1,386 books included anthropomorphic animals, and these were subjected to analysis.

\subsection{Protagonist}

Only anthropomorphic animals appeared as protagonists in 807 picture books and 359 picture books had only human protagonists. Of these, 742 books depicted the protagonists as male only and 655 books presented them as children only (Table 1). Overall, protagonists were most frequently depicted as male, children, and anthropomorphic animals (271 books). Further, 102 books employed only non-anthropomorphic animals, 6 books employed both anthropomorphic and non-anthropomorphic animals, and 4 books employed both humans and anthropomorphic animals, as protagonists in the story.

\subsection{Species of Anthropomorphic Animals}

A large number of animal categories (species) were presented as behaving like humans: 82 mammals, 40 insects, 38 birds, 9 fish and crustaceans, and 9 amphibians or reptiles. Some pictures of birds, insects, and fish were impossible to classify in more detail as actual biological species. Because of the appearance of a wide variety of animals, we extracted 10 species for analysis: rabbits, mice, bears, cats, foxes, dogs, pigs, squirrels, frogs, and raccoon dogs. These animals were depicted in more than 100 books and were the top 10 by number that appeared as anthropomorphic in the books. Except for frogs, nine of these 10 species were mammals.

\subsection{Sex of Anthropomorphic Animals in Each Species}

Table 2 shows, the number of books that depicted the 10 species of animals as male or female or unclear. Overall, many picture books treated the anthropomorphic animals as male or unclear. The chi-square test was significant for the distribution of sex by species $\left(\chi^{2}(18, \mathrm{~N}=3188)=110.897, p<.001\right)$. Residual analysis showed that rabbits appeared significantly more often as female or unclear sex and less often as male. Bears appeared significantly more often as male and less often as unclear. Foxes and dogs appeared significantly more often as male and less often as female. Pigs appeared significantly more often as female and less often as unclear. Squirrels appeared significantly more often as unclear and less often as male. Raccoon dogs appeared significantly more often as unclear and less often as female.

Table 1. Number of picture books in which only anthropomorphic animals or humans were protagonists, by sex and age group.

\begin{tabular}{|c|c|c|c|c|c|c|c|c|c|}
\hline & Male & & Female & & Male and female & & Unclear & & \\
\hline & $\begin{array}{l}\text { Anthropomorphic } \\
\text { animal }\end{array}$ & Human & $\begin{array}{l}\text { Anthropomorphic } \\
\text { animal }\end{array}$ & Human & $\begin{array}{l}\text { Anthropomorphic } \\
\text { animal }\end{array}$ & Human & $\begin{array}{l}\text { Anthropomorphic } \\
\text { animal }\end{array}$ & Human & Total \\
\hline Child & 271 & 115 & 76 & 135 & 26 & 18 & 13 & 1 & 655 \\
\hline Adult & 128 & 43 & 31 & 4 & 7 & 2 & 5 & 3 & 223 \\
\hline Senior & 13 & 17 & 4 & 20 & & & & & 54 \\
\hline $\begin{array}{l}\text { Child } \\
\text { and adult }\end{array}$ & 3 & & 1 & & 13 & & & & 17 \\
\hline $\begin{array}{l}\text { Child, adult } \\
\text { and senior }\end{array}$ & & & & & 3 & & & & 3 \\
\hline $\begin{array}{l}\text { From child to } \\
\text { adult*1 }\end{array}$ & 2 & & & & & & & & 2 \\
\hline Unclear & 149 & 1 & 19 & & 8 & & 35 & & 212 \\
\hline Total & 566 & 176 & 131 & 159 & 57 & 20 & 53 & 4 & 1166 \\
\hline
\end{tabular}

*1Protagonists grew from child to adult in the stories and there was no core age group.

Table 2. Number of picture books in which anthropomorphic animals appeared, by sex and species.

\begin{tabular}{llllllll}
\hline & Male & \multicolumn{2}{l}{ Female } & Unclear & $\begin{array}{l}\text { Picture books } \\
\text { surveyed }\end{array}$ \\
\hline Rabbit & 180 & $* * *$ & 173 & $* * *$ & 207 & $*$ & 415 \\
Mouse & 226 & & 148 & & 193 & & 388 \\
Bear & 225 & $* * *$ & 79 & $*$ & 101 & $* * *$ & 316 \\
Cat & 146 & & 94 & & 136 & & 289 \\
\hline
\end{tabular}

\begin{tabular}{llllllll}
\hline & Male & & Female & Unclear & $\begin{array}{l}\text { Picture books } \\
\text { surveyed }\end{array}$ \\
\hline Fox & 143 & $*$ & 62 & & 89 & & 234 \\
Dog & 137 & $* * *$ & 33 & $* * *$ & 75 & & 198 \\
Pig & 101 & & 68 & $*$ & 63 & $*$ & 174 \\
Squirrel & 62 & $* *$ & 48 & & 82 & $* *$ & 163 \\
Frog & 85 & & 39 & & 57 & & 138 \\
Raccoon dog & 57 & & 21 & $*$ & 58 & $*$ & 110 \\
\hline
\end{tabular}

$* p<.05 . * * p<.01 . * * * p<.001$. 


\subsection{Role of Anthropomorphic Animals in Each Species}

Table 3 shows the number of books in which the 10 species of anthropomorphic animals played different roles. Chi-square test was significant $\left(\chi^{2}(18, \mathrm{~N}=3009)=58.567, p<.001\right)$. Residual analysis showed that bears acted significantly more often as protagonists and less often as background characters. Cats appeared significantly less often as supporting characters. Foxes and squirrels acted as protagonists significantly less often.

Table 3. Number of picture books in which anthropomorphic animals appeared, by role and species.

\begin{tabular}{|c|c|c|c|c|c|c|c|}
\hline & \multicolumn{2}{|c|}{ Protagonist } & \multicolumn{2}{|c|}{$\begin{array}{l}\text { Supporting } \\
\text { character }\end{array}$} & \multicolumn{2}{|c|}{$\begin{array}{l}\text { Background } \\
\text { character }\end{array}$} & \multirow{2}{*}{$\begin{array}{l}\begin{array}{l}\text { Picture books } \\
\text { surveyed }\end{array} \\
415\end{array}$} \\
\hline Rabbit & 97 & & 260 & & 160 & & \\
\hline Mouse & 124 & & 241 & & 161 & & 388 \\
\hline Bear & 111 & $* * *$ & 194 & & 80 & $* * *$ & 316 \\
\hline Cat & 87 & & 155 & $*$ & 116 & & 289 \\
\hline Fox & 42 & $*$ & 143 & & 91 & & 234 \\
\hline Dog & 48 & & 109 & & 79 & & 198 \\
\hline Pig & 46 & & 106 & & 70 & & 174 \\
\hline Squirrel & 16 & $* * *$ & 100 & & 66 & & 163 \\
\hline Frog & 36 & & 85 & & 58 & & 138 \\
\hline Raccoon dog & 21 & & 59 & & 48 & & 110 \\
\hline
\end{tabular}

$* p<.05$. ***p $<.001$.

\section{Discussion}

This study quantitatively examined picture books in which anthropomorphic animals were depicted. We focus on two points to examine the implications of these fantastical animals for children: the features of the protagonists and the properties of each species.

\subsection{Protagonist}

The anthropomorphic animals tended to be protagonists. In picture books in which the anthropomorphic animals appeared, the number of books with these animals as protagonists was almost twice as large as the number with human protagonists. Protagonists who were anthropomorphic animals or humans were predominantly males. These findings concur with the results of previous studies [24, 25].

Matsuoka [26] proposed that animals tend to act as protagonists in picture books because it is necessary for children to integrate themselves with the protagonists in order to incorporate the story into their own experience. Animals are characters that children can easily assign themselves to, because animal's behavior and appearance make them feel like humans, and animals are curious and can move quickly. This can also explain why many protagonists are men and children in picture books. In general, children are active and show interest in a variety of things. There is also a stereotype of men as brave, positive, and active compared with women [27]. Haijima [28] also suggested that seeing animals leads to the joy of looking into another world, and that a story in which anthropomorphism is depicted is attractive to people because it makes animals seem closer to them.

These observations suggest that children enjoy experiences in other worlds by projecting themselves onto animals and immersing themselves in the fascinating world that the animals present. This increases their experience in a variety of worlds through stories and develops their imaginative world more richly.

\subsection{Species of Anthropomorphic Animals}

Mammals appeared frequently as anthropomorphic animals, and children should be more familiar with them. Rabbits were the most common, followed by mice and bears.

\subsubsection{Rabbit and Mouse}

Rabbits and mice are small animals, herbivores that are often victims in nature. Yano [22] has described them as small and weak, in contrast with many other animals. Thus children, who are smaller and weaker than adults, may be able to project themselves onto rabbits and mice.

Children gradually acquire perceptions of themselves sensorially and physically from the time they are born. Self-awareness grows through the formation of self-images that incorporate values, evaluations, and emotions generated through interaction with others. Thus they acquire perspective of self from others' standpoints and deepen their psychological self-awareness [29]. Yano [22] has suggested that when a weak little mouse is depicted as greater than bigger creatures, children will superimpose themselves on the mouse. The characters of rabbit and mouse are attractive to children who are in the stage of gradually expanding the range of their world from home to day-care centers, kindergartens, and schools. Yano [22] also proposed several reasons that rabbits appear as protagonists in many picture books: (a) rabbits have distinctive long ears and are easy to draw, (b) animals that jump are attractive to children, because jumping makes children feel the joy of being released from gravity, and (c) the burrows where rabbits live are deep and cannot be seen from the outside, which makes children imagine them as gateways to a different world. In this way, the innate characteristics of mice and rabbits attract children and enrich their imaginative world, and these animals are frequently depicted in children's books.

\subsubsection{Bear}

Bears are large, dangerous animals that sometimes attack humans, but they can also be affectionately depicted and loved. It is conceivable that the two contradictory aspects of a bear's fearsomeness and cuteness make it attractive as a character in picture books. A typical example is a teddy bear, whose shape is in exquisite balance with the baby schema, a stimulus that exhibits cuteness [30]. A large face is one of the features of baby schema. The face is important for communication and can bring an animal closer to the human image, suggesting a connection between the baby schema and anthropomorphism of animals [31]. The technique of drawing an animal by emphasizing its head has been described by Yano [22], as one of the techniques by which 
anthropomorphism expresses itself in picture books. Furthermore, humans prefer round shapes [32], which are related to concepts such as safety and female [33]. Round shapes give peace of mind without threat and contribute to feelings of cuteness [31]. The chubby and bulky shape of bear is easy to draw as illustrations suitable for picture books, and with attractiveness of two-sided nature, bears in picture books could be loved by children.

\subsection{Sex and Role of Anthropomorphic Animals}

Among the many animals that appeared in the picture books, bears, dogs, foxes, and raccoon dogs were often depicted as male, and rabbits and pigs were often depicted as female. From an evolutionary point of view, bears, dogs, foxes, and raccoon dogs share a common ancestral carnivore, Miacines [34], and are very different from herbivorous rabbits and pigs.

\subsubsection{Bear}

Bears were often depicted as male and acted as protagonists. They are dangerous animals and have long been feared by humans; in Europe, bears were considered the king of beasts. A bear has a huge and strong body, and their heavy appearance is emphasized by the large muscles in front of the body [35]. Bears' innate strength and chunky morphology are consistent with the masculine stereotype of strong, aggressive, dominant, and wild [27].

In this way, bears are linked to the male image, and the virile impression of bears is reflected in picture books. The characteristics of the male characters as protagonists in this study are consistent with those identified in previous research $[24,25]$. Thus one of the reasons why bears are often used as protagonists is that they present a strong and masculine image in addition to their attractiveness as animals.

\subsubsection{Dog}

Dogs were often depicted as male. Dogs were domesticated from wolves and have a history of being hunting partners with great sociability. Dogs have long lived and worked with humans [36] and have an image as watchdogs and faithful companions [37]. Dog keepers believe that dogs are more attached to their keepers and are more active than cats [38]. It is possible that the dog's historic role in working outside with men has led to the establishment of an active and courageous image that is linked to the image of men.

\subsubsection{Fox}

Foxes were often depicted as men, but less often as protagonists. Foxes often appear in Russian animal folklore, and in the Russian language, the adjectives that are often used to describe foxes give the impression that foxes are not only cunning but also clever [39]. Foxes are characterized as heels, which bully or flirt with protagonists, and as animals who are calculating and skillfully interfere with protagonists. This may be the reason that foxes were less often depicted as protagonists in the picture books. The image of foxes as crafty and smart is also found in Japanese works, where they are often depicted as males, and villains who interfere with protagonists [40]. Foxes have not been domesticated, and despite the passage of time, the relationships between Japanese people and foxes has not changed. The image of foxes as sly and mischievous derives from the impression that foxes deceive people. Furthermore, Iwata and Fujimoto [40] have pointed out that in Japanese picture books, the masculine first person pronoun "ore," which creates a violent and heroic impression, is often used for foxes in order to depict them as malicious characters.

However, Japanese folklore describing marriages between men and foxes in the shape of women were once common [41]. Later, supernatural stories about foxes spread into Japan from China, and people began to fear foxes disguised as women who deceived men sexually [42, 43]. These stories about foxes in Japan suggest that foxes have some connection with the image of women. Nevertheless, the foxes in the picture books were often depicted as men acting in cynical and mischievous ways.

\subsubsection{Raccoon Dog}

Raccoon dogs live in throughout East Asia, and the following discussion focuses on their image in Japan. In the picture books, their sex was frequently unclear, and they were less often depicted as women, although it was difficult to judge raccoon dogs as relatively male. However, based on changes in the way they have been treated in Japanese folklore and legends, raccoon dogs have a masculine image. Nakamura [44] described the position of the raccoon dogs in Japanese culture as follows: In the Middle Ages, they used to be specters (yokai) that bewitched humans in the mountains. Their impressions as specters, combined with feminine elements as mountain goddesses, led to the spread of a mysterious phenomenon in which raccoon dogs temporarily appeared in female form. At that time, however, foxes, which (in contrast to raccoon dogs) were animals, became messengers of god. The masculinization of raccoon dogs progressed in conjunction with foxes, which were thought to be able to transform into women. In the early-modern times, because of the raccoon dogs' habit of climbing trees, there were many stories in which people outside were attacked by raccoon dogs from above. Such aggressive and violent images among the gender stereotypes for men [27]. Later, many legends about raccoon dogs were associated with monks, and the male image of raccoon dogs became established. In the late 17 th century, a story about raccoon dogs with very large scrota began to appear, and in the early 20th century, a male raccoon dog ornament or statue (Shigaraki ware) became popular; both phenomena strengthened the maleness of the raccoon dog. Through this process, the past image of raccoon dogs as female in Japan has become less familiar today and may therefore be suppressed in picture books.

\subsubsection{Rabbit}

The image of rabbits as female may be related to the fact that rabbits are socially accepted as being cute. Hattori, et al. [45] examined coloring of a rabbit by children from 1 to 10 
years old; many painted the rabbit pink. When asked about their image of rabbits, more than $90 \%$ of them responded "cute." Kiyosawa [46] reported that more than half of Japanese woman, regardless of age, chose baby pink, pink, and coral as "cute" colors. In addition, among the relationships between animal species and language, rabbits have been associated with feminine speech [40]. This suggests that images of rabbits as cute and feminine are widely established, and this is reflected in picture books.

Furthermore, rabbits played gender-related-roles in the picture books in this study, most often acting as supporting characters. A already noted, rabbits are strongly associated with a feminine image, and because women are stereotyped as submissive, gentle, and peaceful [27], rabbits were portrayed as playing supportive roles in the stories, rather than acting as heroines who were brave and strong. Images of women in supporting roles also occur in real life. In a study of junior high school students conducting science experiments, Kawano [47] reported that the girls, rather than the boys, tried to facilitate the experiment by playing supporting or peripheral roles. In an examination of children's TV programs and picture books, Fujita [25] found that men played the leading roles and women played supporting and peripheral roles. Thus it is possible that supportive images associated with women were presented through rabbits in picture books.

\subsubsection{Pig}

Pigs were often depicted as females, perhaps because of their shape. Round and plump figures such as those of pigs are associated with femininity. Iino [48] examined perceived images of gender and found that the physical characteristics of curvilinear figures and softness are images of femininity. Pigs, when presented in simplified illustrations, are sometimes drawn more rounded than those in real life. A round shape gives the impression of safety and femininity [33]. Further, pink, the color associated with cuteness [46], is often used for the body color of pigs. In modern pig production, major breeds such as Big Yorkshire and Landrace have white body hair through which pink skin can be seen [49]. Words often associated with pigs are "pink" and "cute" [50]. In the illustrations in the picture books, pigs were mainly drawn in pink, and were associated with images of plump bodies and female figures.

\subsubsection{Squirrel}

In picture books, there were few squirrel protagonists, and many of them were of unclear sex. Because squirrels have arboreal habitats, they have less contact with people. In addition to the psychological distance between trees and the ground, there is also a spatial division between villages and forests. Chiba [43] noted that the Japanese understanding of squirrels was extremely inaccurate in the past, because squirrels were unfamiliar to Japanese people who lived in flat areas. Partly because the habitats of squirrels in Japan were limited, a standard Japanese word for squirrels did not exist until the latter half of the 17th century, and squirrels seldom appeared in animal folklore or in oral literature. Based on vies from the past, squirrels are animals with few points of contact among humans and remain largely unfamiliar; thus squirrels are not likely protagonists and are often depicted in picture books without revealing their sex.

\subsubsection{Cat}

Cats seldom appeared as supporting characters in the picture books. The cat family is mainly solitary, and cats have an image of strong independence. Studies have shown that cats have a high level of self-reliance. Miklósi, Pongrácz, Lakatos, Topál and Csányi [51] examined the communication behaviors of dogs and cats toward humans, and found that cats, compared with dogs, are less likely to rely on their owners and more likely to solve problems by themselves. This self-reliance of cats is fascinating to humans. Surpell [52] examined the relationships between dog/cat behavior and owner attachment. Cat's made fewer expressions of affection to their owners than dogs did, but there was no difference in the affection the owners had for their dogs and cats. The fact that cats are identified as animals that do not get along with others and have an independent way of life suggests why cats are depicted in stories as animals that are rarely involved deeply. Indeed, there were few cases in the picture books in which cats interacted with the protagonists or other characters.

\subsubsection{General Features}

Some anthropomorphic animals were depicted without an explicit sex. Obscuring their sex not only increases the generality of the story but also helps to maintain a sense of distance of the animals from the reader. Sex is a significant piece of information for a character, and having the animal identified with a gender contributes to its likely background. It is possible that using anthropomorphic animals in stories as human-like creatures, while at the same time suggesting they are different from humans, creates a sense of mystery for the reader.

However, previous research has suggested that many animals depicted in picture books without a clear sex are perceived by readers as male [53]. This may be attributable to an erroneous transfer that occurs when nursery school teachers or other adults in English-speaking countries read aloud and use male pronouns (he) for animals. In other languages like Japanese, in which such pronouns are not frequently used, bias of parents and caregivers with respect to gender images of animals may be transmitted to children, and thus it is possible that anthropomorphic animals are interpreted as male more frequently than found this study.

\section{Conclusion}

This survey of 1,386 animal picture books found that a wide variety of animals were portrayed by means of anthropomorphism. Mammals tended to be anthropomorphized, and the most frequently appearing anthropomorphic animals were, in order, rabbits, rats, and bears. The protagonists in picture books frequently included anthropomorphic animals, children, and males. In 
addition, different species of anthropomorphic animals were depicted with different characteristics of sex and roles. Many picture books described bears, dogs, and foxes as males and rabbits and pigs as females. Bears tended to be protagonists, squirrels and foxes were less likely to be protagonists, and cats were less likely to act as supporting characters. These results confirmed that children see various kinds of anthropomorphic animals in picture books and that the animals in the books reflect their social images and their history with humans. This suggests that children's images of animals are influenced by picture books.

Future studies should compare the depictions of animals by analyzing realistic as well as anthropomorphic animals drawn in picture books. More detailed analyses of each animal species will also be informative. Further research on picture books, which provide children with indirect contact with animals, is expected to serve as a steppingstone to improve the relationships between children and animals, and thus between humans and animals.

\section{Acknowledgements}

The authors would like to thank H. Shimatani for useful discussion.

\section{References}

[1] Kato, Y. (2018, December 20), Sales of picture books increases with support of grandparents. The Asahi Shimbun, morning edition, p. 34. (in Japanese)

[2] Ministry of Education, Culture, Sports, Science and Technology. (2017). The national curriculum standard for kindergartens. Retrieved October 9, 2020, from https://www.mext.go.jp/component/a_menu/education/deta il/_icsFiles/afieldfile/2019/10/11/1401777_002.pdf.

[3] Wasik, B. A., Hindman, A. H., and Snell, E. K. (2016). Book reading and vocabulary development: A systematic review. Early Childhood Research Quarterly, 37 (4), 39-57.

[4] Horst, J. S. (2013). Context and repetition in word learning, Frontiers in Psychology, 4, art. 149.

[5] Fletcher, K. L., and Reese, E. (2005). Picture book reading with young children: A conceptual framework. Developmental Review, 25 (1), 64-103.

[6] Strouse, G. A., Nyhout, A., and Ganea, P. A. (2018). The role of book features in young children's transfer of information from picture books to real-world contexts. Frontiers in Psychology, 9, art. 50.

[7] Horst, J. S., and Houston-Price, C. (2015). Editorial: An open book: What and how young children learn from picture and story books, Frontiers in Psychology, 6, art. 1719.

[8] Abad, C., and Pruden, S. M. (2013). Do storybooks really break children's gender stereotypes? Frontiers in Psychology, 4, art. 986.

[9] Heath, P., Houston-Price, C., and Kennedy, O. B. (2018). Let's look at leeks! Picture books increase toddlers' willingness to look at, taste and consume unfamiliar vegetables. Frontiers in Psychology, 5, art. 191.

[10] Flevares, L. M., and Schiff, J. R. (2014). Learning mathematics in two dimensions: A review and look ahead at teaching and learning early childhood mathematics with children's literature. Frontiers in Psychology, 5, art. 854.

[11] Ganea, P. A., Ma, L., and DeLoache, J. S. (2011). Young children's learning and transfer of biological information from picture books to real animals. Child Development, 82 (5), 1421-1433.

[12] DeLoache, J. S., Pickard, M. B., and LoBue, V. (2011). How very young children think about animals. In P. McCardle, S. McCune, J. A, Griffin, V. Maholmes (Eds.), How animals affect us: Examining the influence of human-animal interaction on child development and human health (pp. 85-99). Washington, DC: American Psychological Association.

[13] LoBue, V., Pickard, M. B., Sherman, K., Axford, C., and DeLoache, J. S. (2013). Young children's interest in live animals. British Journal of Developmental Psychology, 31 (1), 57-69.

[14] Marriott, S. (2002). Red in tooth and claw? Images of nature in modern picture books. Children's Literature in Education, 33, 175-183.

[15] Waxman, S. R., Herrmann, P., Woodring, J., and Medin, D. L. (2014). Humans (really) are animals: picture-book reading influences 5-year-old urban children's construal of the relation between humans and non-human animals, Frontiers in Psychology, 5, article 172.

[16] Ganea, P. A., Canfield, C. F., Simons-Ghafari, K., and Chou, T. (2014). Do cavies talk? The effect of anthropomorphic picture books on children's knowledge about animals, Frontiers in Psychology, 5, art. 283.

[17] Newman, C. (2014). Hey kids, all deer aren't like Bambi. National Geographic, Retrieved October 9, 2020, from https://www.nationalgeographic.com/news/2014/3/140327childrens-books-fantasy-animals-psychology.

[18] Uchida, N. (1994). Monogatari kodo no hattatsu [The development of narrative behavior]. In N. Uchida (Ed.), Developmental psychology of reading, writing and talking. Foundation for the Promotion of The Open University of Japan. (in Japanese).

[19] Uchida, N. (2002). Sekai wo toraeru shikumi: Shocho kinou no hattatu to kotoba no kakutoku [The mechanism for grasping the world: Development of symbolic functions and language acquisition]. In N. Uchida (Ed.), Developmental psychology. Foundation for the Promotion of The Open University of Japan. (in Japanese).

[20] Uchida, N. (1994). Sozo ryoku [The imagination]. Kodansha. (in Japanese).

[21] Matsui, T. (1973). Ehon toha nani ka [What are picture books?]. Japan Editor School Press. (in Japanese).

[22] Yano, S. (2002). Dobtssu ehon wo meguru boken [Adventures over animal picture books]. Keiso Shobo. (in Japanese).

[23] McCrindle, M. E., and Odendaal, J. S. (1994). Animals in books used for preschool children. Anthrozoös, 7 (2), 135-146. 
[24] Banzai, T., and Osawa, H. (1989). A study on sex roles in picture books. Journal of Saitama University. Science of Education, 38 (2), 15-38.

[25] Fujita, Y. (2003). Gender in mass media for children: An analysis of television and books. Journal of Kyushu University of Health and Welfare, 4, 259-268.

[26] Matsuoka, K. (1987). Ehon no sekai, kodomo no sekai [Picture books' world: Children's world]. Japan Editor School Press. (in Japanese).

[27] Dohi, I. (2004). "Danjo no omoikomi" wo tsukuru kokoro no shikumi [The mental systems making "male and female assumptions"]. In Jenda no shinrigaku kaiteiban (pp. 26-47). Minerva Shobo. (in Japanese).

[28] Haijima, K. (2017). Ehon wo fukaku yomu [Reading picture books deeply]. Tamagawa University Press. (in Japanese).

[29] Kashiwagi, K. (1994). Ziko ninshiki no hattatu to keisei [Development and formation of self-awareness]. In T. Noro (Ed.), Developmental psychology revised edition. Foundation for the Promotion of The Open University of Japan. (in Japanese).

[30] Lorenz, K. (1943). Die angeborenen Formen möglicher Erfahrung. Zeitschrift für Tierpsychologie, 5 (2), 235-409.

[31] Nittono, H. (2019). "Kawaii" no chikara [The power of "cute"]. Kagakudouzin. (in Japanese).

[32] Bar, M., and Neta, M. (2007). Visual elements of subjective preference modulate amygdala activation. Neuropsychologia, $45,2191-2200$.

[33] Palumbo, L., Ruta, N., and Bertamini, M. (2015). Comparing angular and curved shapes in terms of implicit associations and approach/avoidance responses. PLoS ONE, 10 (10), e0140043.

[34] Flynn, J. J., and Galiano, H. (1982). Phylogeny of early tertiary carnivora: with a description of a new species of protictis from the middle Eocene of northwestern Wyoming. American Museum Novitates, 2725, 1-64.

[35] Pastoureau, M. (2014). The bear: History of a fallen king (Hirano, T., Trans.). Le Seuil. (Original work published 2007).

[36] Thorne, C. (1997). Evolution and domestication. In C. Thorne (Ed.), The Waltham book of dog and cat behaviour (pp. 1-30). Pergamon Press.

[37] Ikushima, H. (2017). Analysis of expressions associated with "dog" and "cat" images in sandplay works: compared works of university students with those of teachers. Research Bulletin of Tokushima Bunri University, 94, 15-28.

[38] Konno, A., and Nihei, Y. (2007). Development of a temperament scale for dogs and cats. Proceedings of the 5th Conference of the Japanese Society for Cognitive Psychology, 85 .
[39] Mizukami, N. (2008). The fox, the bear and the wolf in Russian animation films. The Bulletin of Niigata Women's College, 45, 365-378.

[40] Iwata, M., and Fujimoto, M. (2014). Talking animals: images of animals as characters. Gobun, 103, 43-54. (in Japanese).

[41] Nakamura, T. (2001). Kitsune no nihonshi: Kodai chusei hen [Japanese history of foxes: ancient and middle age]. Japan Editor School Press. (in Japanese).

[42] Nakamura, T. (2006). Nihonjin no Dobutsu kan [Japanese view and attitude toward animals]. Seiunsha. (in Japanese).

[43] Chiba, T. (1992). Honyurui [Mammals]. In Nihonshi no naka no dobutsu jiten (pp. 2-78). Tokyodo Shuppan. (in Japanese).

[44] Nakamura, T. (1990). Tanuki to sono sekai [The raccoon dogs and their world]. Asahi Sensho. (in Japanese).

[45] Hattori, M., Horiuchi, T., Katsuno, K., Itagaki, H., Kato, K., Inoue, Y., Maeda, M., Hanazono, M., and Akao, H. (2007). Why do children color rabbits pink? Thinking of Animals, 12, 23-28.

[46] Kiyosawa, T. (2014). Classification of test subjects and its taste characteristic based on experimental results of "kawaii" color. Transactions of Japan Society of Kansei Engineering, 13 (1), 107-116.

[47] Kawano, G. (2004). Rikabanare ha honto $\mathrm{ka}$ [Is it true that people are away from science?]. In T. Matsumura (Ed.), Who is away from science? Gender analysis of Japanese junior high school students survey (pp. 13-36). Nippon Hyoron sha. (in Japanese).

[48] Iino, H. (1998). Image of "manliness" and "femininity" held by university students, Proceeding of the Annual Meeting of Japan Society of Personality Psychology, 7, 80-81. (in Japanese).

[49] Suzuki, K. (2014). Buta no kigen to kairyo no rekishi [The history of the origin and improvement of pigs]. In K. Suzuki (Ed.), Series science of livestock 2. Asakura Publishing. (in Japanese).

[50] Kamizono, K. (2011). Change of consciousness in audiences by viewing the movie "Classroom with a Pig". Bulletin of Faculty of Education, Nagasaki University. Educational Science, 75, 1-9.

[51] Miklósi, A., Pongrácz, P., Lakatos, G., Topál, J., and Csányi, V. (2005). A comparative study of the use of visual communicative signals in interactions between dogs (Canis familiaris) and humans and cats (Felis catus) and humans. Journal of Comparative Psychology, 119 (2), 179-186.

[52] Surpell, J. A. (1996). Evidence for an association between pet behavior and owner attachment levels. Applied Animal Behaviour Science, 47 (1-2), 49-60.

[53] DeLoache, J. S., Cassidy, D. J., and Carpenter, C. J. (1987). The three bears are all boys: Mothers' gender labeling of neutral picture book characters. Sex Roles, 17 (3-4), 163-178. 